\title{
Počátky opery ve Slezsku - současný stav pramenů
}

\section{The Origins of the Opera in Silesia - the Current State of Sources}

Jiřímu Sehnalovi k 85. narozeninám

Jana Spáčilová / jana.spacilova@upol.cz

Katedra muzikologie FF UP, Olomouc, CZ

\begin{abstract}
The study deals with the Italian Opera in Breslau (Wrocław) in 1725-1734. It focuses on the overview and brief descriptions of the known sources - librettos, scores and news from the contemporary press Schlesischer Nouvellen-Courier. Also included is a table with the currently identified librettos, including their storage.
\end{abstract}

\section{Key words}

Opera, Wrocław (Breslau), libretto, score, Antigona, Giuseppe Maria Orlandini, Antonio Bioni, Schlesischer Nouvellen-Courier 
Italská opera ve střední Evropě první poloviny 18. století je tématem, k němuž se v poslední době obrací pozornost těch hudebních historiků, kteří se pokoušejí vnímat lokální hudební kulturu nejen z hlediska pěstování národní hudby, nýbrž v širším evropském kontextu. ${ }^{1}$ Jedním z průkopnických počinů tohoto výzkumu se stala esenciální studie Jiřího Sehnala Počátky opery na Moravě. Současný stav vědomostí, na jejíž vzor si dovoluji odkázat názvem předkládaného textu. ${ }^{2}$ Tato stat’ v době svého zveřejnění významně doplnila starší výzkumy Vladimíra Helferta o operním provozu na zámku hraběte Questenberga v Jaroměřicích nad Rokytnou a stala se odrazovým můstkem pro výzkum italské opery na Moravě v 1. polovině 18. století, který je od roku 2005 realizován na půdě moravských muzikologických a teatrologických institucí. ${ }^{3}$ Nejvýznamnějšími dosud publikovanými výsledky tohoto výzkumu jsou nová jaroměřická monografie Jany Perutkové a kniha o brněnském městském divadle Margity Havlíčkové (obě vyšly také v němčině). ${ }^{4}$

Jedním z nejdůležitějších zdrojů pro výzkum recepce italské opery za Alpami jsou tištěná libreta. Tímto typem pramene se intenzivně zabývám několik posledních let v souvislosti s přípravou katalogu libret oper provedených před rokem cca 1750 na Moravě (tj. v městském divadle v Brně a na soukromých šlechtických scénách v Jaroměřicích, Vyškově, Kroměříži a Holešově). ${ }^{5}$ Během výzkumu jsem narazila na problém personální i repertoárové návaznosti moravského operního provozu na další středoevropská operní centra, zejména Prahu a Vratislav. Italská opera v Praze je předmětem soustavného odborného zájmu a díky výzkumům Tomislava Volka, Milady Jonášové a Daniela E. Freemana je již poměrně dobře zpracována, zdejší libreta jsou navíc uložena v pražských knihovnách a tedy bez větších problémů přístupná. ${ }^{6}$ Oproti tomu, souhrnné informace o opeře ve Vratislavi lze spolehlivě čerpat pouze z více než sto let staré studie Hanse

1 Předkládaný text je rozšířenou verzí referátu „Italská opera v 1. polovině 18. století mezi Prahou, Brnem a Vratislaví“, který byl přednesen na konferenci „Hudba v zemích Koruny české v raném novověku - ad honorem Georgii Sehnal (2. část)“, konané ve Slezských Rudolticích dne 27. 5. 2016. Studie je výstupem projektu financovaného Grantovou agenturou České republiky (GA16-17615S).

2 SEHNAL, Jiří. Počátky opery na Moravě. Současný stav vědomostí. In PETRU゚, Eduard, ed. $O$ divadle na Moravě. AUPO, Facultas philosophica, Supplementum 21. Praha: SPN, 1974, s. 55-77.

3 PERUTKOVÁ, Jana - SPÁČILOVÁ, Jana. Italská opera na Moravě - fenomén stále aktuální. Opus musicum, 2005, roč. 37, č. 5, s. 50-53. K první etapě výzkumu viz PERUTKOVÁ, Jana. Výsledky projektu „Italská opera na Moravě v 1. polovině 18. století“ se zvláštním zřetelem k nově identifikované sbírce partitur hraběte Johanna Adama Questenberga (1678-1752). In: Miscellanea z výročnich konferenci ČSHV. Praha: EÚ AV ČR, 2008, s. $126-134$.

4 PERUTKOVÁ, Jana. František Antonín Míca ve službách hraběte Questenberga a italská opera v Jaroměricích. Praha: KLP, 2011. Táž. Der glorreiche Nahmen Adami. Johann Adam Graf von Questenberg (1678-1752) als Förderer der italienischen Oper in Mähren. Wien: Hollitzer, 2015. HAVLÍČKOVÁ, Margita. Profesionálni divadlo v královském městě Brně 1668-1733, Brno: JAMU, 2009. Táž. Berufstheater in Brünn 1668-1733, Brno: MU, 2012.

5 SPÁČILOVÁ, Jana. Catalogue of the Italian Opera Libretti in Central Europe in the 1st Half of the 18th Century, I: Moravia. Clavis monumentorum musicorum regni Bohemiae, series S, VIII. Praha: KLP, v tisku.

6 FREEMAN, Daniel E. The Opera Theater of Count Franz Anton von Sporck in Prague. Studies in Czech Music 2, Stuyvesant - New York: Pendragon Press, 1992. VOLEK, Tomislav. Italská opera a další druhy zpívaného divadla. In ČERNÝ, František, ed. Divadlo v Kotcích. Nejstarší pražské městské divadlo 1739-1783, Praha: Panorama, 1992, s. 43-56. JONÁŠOVÁ, Milada. I Denzio: tre generazioni di musicisti a Venezia e a Praga. Hudebni věda, 2008 , roč. 45 , č. $1-2$, s. 57-114. 
Heinricha Borcherdta Geschichte der italienischen Oper in Breslau. ${ }^{7}$ Nejnovější práce Walentyny Węgrzyn-Klisowské Barokowy teatr operowy we Wroctawiu 1725-1734 nepředstavuje víc než pouhý pokus o shrnutí problematiky. ${ }^{8} \mathrm{~V}$ první fázi proto bylo nutno ověřit a doplnit stav pramenné základny, která se od počátku 20. století pochopitelně zásadně proměnila. Předkládaný text proto představuje první pokus o shromáždění dosud známých pramenů k italské opeře ve Vratislavi, přičemž jejich podrobná analýza a zhodnocení zůstávajî úkolem budoucího výzkumu.

Vratislav (Wrocław, Breslau), do roku 1742 hlavní město Slezska jako jedné ze zemí Koruny České, se stala v těsném sledu po Praze druhým městem za Alpami, v němž se rozvinula soustavná tradice veřejně přístupných operních představení. Od jara 1725 do počátku roku 1734 zde působila italská operní společnost, vzniklá odštěpením části umělců, kteří přišli v létě roku 1724 pod vedením Antonia Marii Peruzziho a Antonia Denzia z Benátek do Čech. S pražskou Denziovou společností zůstali italští operisté ve Vratislavi v úzkém kontaktu i nadále. Není ale pravda, jak tvrdí Freeman, že Vratislav byla pouhou „operní kolonií Prahy“, protože repertoár i umělci putovali oběma směry. ${ }^{9}$ Mezi jmény, která se vyskytují ve Vratislavi i Praze, navíc najdeme zpěváky, kteří se později objevili i v dalších centrech zaalpské opery, především v Brně, Vídni a Štýrském Hradci. Vedoucí osobností vratislavské společnosti byl benátský skladatel Antonio Bioni, ${ }^{10}$ v počáteční fázi se uplatnil rodák ze Stuttgartu Daniel Gottlieb Treu, vystupující pod italským jménem Theophilo Fedele.

O vratislavském operním dění nás zpravuje dobově výjimečný pramen, jímž je pasáž v Treuově životopisu otištěném v biografickém lexikonu Grundlage einer Ehrenpforte Johanna Matthesona roku $1740 .{ }^{11}$ Původcem tohoto textu byl místní varhaník Johann Georg Hoffmann, který působil jako druhý cembalista společnosti. Podle něho bylo ve Vratislavi provedeno za dobu deseti let celkem 41 italských oper; Hoffmann udává nejen jejich názvy a autory textu a hudby, ale také informace o pěveckém obsazení a v několika př́ípadech i hlasové charakteristiky sólistů. Na rozdíl od jiných lokalit, kde je nutno repertoár teprve pracně rekonstruovat na základě dochovaných libret a dalších pramenů, máme tedy v případě Vratislavi k dispozici kompletní seznam nastudovaných děl, navíc s přidanou hodnotou osobní zkušenosti přímého účastníka.

Autorem více než poloviny zde uvedených oper byl Antonio Bioni, přičemž se často jedná o tituly, které byly krátce předtím zhudebněny Antoniem Vivaldim. Dalším rysem vratislavského repertoáru, který není v dobovém kontextu příliš obvyklý, je napojení

7 BORCHERDT, Hans Heinrich. Geschichte der italienischen Oper in Breslau. Zeitschrift des Vereins für Geschichte Schlesiens, 1910, roč. 44, s. 18-51.

8 WĘGRZYN-KLISOWSKA, Walentyna. Barokowy teatr operowy we Wroctawiu 1725-1734. Wrocław: PSPŚ, 2006.

9 FREEMAN, op. cit., s. 74.

10 K Bionimu zejména: VEVERKOVÁ, Zuzana. Antonio Bioni - životní osudy a tvorba neznámého skladatele. Opus musicum, 2012, roč. 44, č. 3, s. 38-47. PEGAH, Rashid-Sasha. Antonio Bioni und seine „Cantate Musicali“ für Markgräfin Friderique Louise von Brandenburg-Ansbach. Jahrbuch für fränkische Landesforschung, 2012, roč. 72, s. 185-197.

11 Verzeichnis aller welschen Opern, welche von 1725 bis 1734 auf dem breslauischen Schauplatz vorgestellet worden sind. In MATTHESON, Johann. Grundlage einer Ehrenpforte, Hamburg, 1740, s. 374-378. 
na dvorní operu ve Vídni, které se projevilo v provedení tří oper Francesca Bartolomea Contiho v sezóně 1725/26 (Il trionfo dell'amore e dell'amicizia, Alba Cornelia a Il finto Policare). Z Itálie byly pro Vratislav přejaty pouze tři opery. První z nich byla roku $1725 \mathrm{La}$ costanza combattuta in amore Giovanniho Porty, premiérovaná v Benátkách 1716. Spojovacím článkem byl zřejmě zpěvák Paolo Vida, který se zúčastnil provedení této opery ve Veroně v karnevalu 1723. ${ }^{12}$ Druhou byla Didone Tomasa Albinoniho, provedená ve Vratislavi v listopadu 1726, velmi krátce po své benátské premiéře v karnevalu 1725. Obě tyto opery byly později hrány v Praze - Costanza na podzim 1728 a Didone na jaře 1731. Třetí operou, která přišla do Vratislavi zřejmě přímo z Itálie, byla Antigona Giuseppe Marii Orlandiniho, provedená pod názvem Antigona vendicata na podzim 1728. Premiéra opery se odehrála v roce 1718 v Benátkách, vratislavská verze vychází z třetího benátského uvedení roku $1724 .{ }^{13}$ Zbývající vratislavské opery lze zařadit do žánru pasticcia.

Dobově autentické informace o provedeném repertoáru se podařilo doložit téměř ze dvou třetin dochovanými librety, do dnešního dne byla zjištěna existence 26 tisků (viz tabulka). ${ }^{14}$ Většina vratislavských libret - celkem 16 titulů ve čtyřech svazcích plus několik jednotlivých duplikátů - je uložena v místní univerzitní knihovně (Biblioteka Uniwersytecka Wrocław). Jejich uložení uvádí Borcherdt, Sartoriho katalog libret je s výjimkou jediného titulu neeviduje. ${ }^{15} \mathrm{Na}$ druhé straně Sartori zachycuje tři jiné fondy, v nichž se nacházejí ve větším počtu další vratislavská libreta, často unikátně: Biblioteca Nazionale Braidense v Miláně (z fondu Algarotti), Biblioteca di Conservatorio Santa Cecilia v Ř́mě (fond Carvalhaes) a Library of Congress ve Washingtonu. Mezi nověji identifikovaná libreta patří unikátní La costanza combattuta in amore v Biblioteka Narodowa Warszawa ${ }^{16}$ a duplikátní exemplář Andromaca v knihovně Fondazione Cini v Benátkách. Významný posun v poznání vratislavské opery představuje unikátní libreto Antigona vendicata uložené v Oddělení dějin hudby Moravského zemského muzea, zejména proto, že se jedná o srovnávací materiál k nově identifikované partituře této opery (viz dále). Nalezená libreta doplňují informace uváděné Matthesonem, i když v některých případech kolacionování obou zdrojů přináší další otázky, např. co se týče názvu opery (u většiny libret uložených ve Vratislavi je dochován pouze německý titulní list) či autorů textu a hudby.

Hudebních materiálo̊ je nepoměrně méně. Je to dáno tím, že libreta bývala vydána tiskem v počtu několika stovek kusů a byla uchovávána návštěvníky jako připomínka představení, zatímco rukopisné partitury a party byly provozním materiálem a po použití ztrácela jejich existence opodstatnění. Jednoznačně lze přiřadit k Vratislavi prozatím

12 Libreto La costanza combattuta in amore (Verona 1723), I-Mb Racc.dramm.2247. Paolo Vida vystoupil ve Veroně v téže roli, kterou zpíval i ve Vratislavi.

13 K tomuto zjištění jsem dospěla na základě srovnání s librety všech předchozích verzí této Orlandiniho opery: Antigona (Benátky 1718), I-Mb Racc.dramm.2267, Antigona (Benátky 1721), I-Mb Racc.dramm.1839, Antigona (Benátky 1724), I-Mb Racc.dramm.0814, Antigona (Pesaro 1723), I-Bc Lo.3570, Antigona (Torino 1727), I-Bc Lo.3572, La fedeltà coronata (Bologna 1727), I-Bc Lo.3593.

14 Za pomoc s identifikací některých exemplářo̊ a komunikací s jejich vlastníky srdečně děkuji Zuzaně Veverkové.

15 SARTORI, Claudio. I libretti italiani a stampa dalle origini al 1800. Catalogo analitico con 16 indici. Cuneo: Bertola e Locatelli, 1990-1994.

16 Uložení uvádí WĘGRZYN-KLISOWSKA, op. cit., s. 38. 
pouze tři partitury, z nichž jen jediná zachycuje podobu kompletní opery. Je to Issipile Antonia Bioniho, jejíž premiéra se odehrála ve Vratislavi v červenci 1732 při př́ležitosti volby biskupa Filipa Ludvíka kardinála Sinzendorffa. Partitura dnes uložená ve Vídni pochází z hudební sbírky hraběte Questenberga, opera byla žrejmě v listopadu 1737 v Jaroměřicích také provedena. ${ }^{17}$ Druhá, před nedávnem nalezená partitura zaznamenává árie z opery Andromaca Antonia Bioniho, premiérované ve Vratislavi v karnevalu 1730. Partitura je uložená v knihovně polské akademie věd v Kórniku, v roce 2006 zazněla část árií z této opery v obnovené světové premiéře. ${ }^{18}$

K těmto dvěma hudebním pramenům lze nyní nově přiřadit třetí - partituru opery Giuseppe Marii Orlandiniho Antigona, provedené ve Vratislavi na podzim $1728 .{ }^{19}$ Partitura pocházející z hudební sbírky chotkovského zámku Kačina nese titul Opera del'Antigona, jméno skladatele není uvedeno. Vratislavská provenience byla potvrzena jednak analýzou kopistů, ${ }^{20}$ jednak srovnáním s výše zmíněným libretem Antigona vendicata. Pramen obsahuje až na jediné všechna hudební čísla obsažená v libretu, byṫ zapsaná v nesprávném pořadí. Z rozložení kopistických složek lze však poznat, že árie nebyly opisovány jednotlivě, nýbrž najednou, a jejich pořadí tedy zřejmě bylo zpřeházené již v předloze. Četné chyby v italském textu svědčí o zběžné práci opisovačů. V závěru partitury je přivázán zvláštní list s basovým partem, který je možno identifikovat jako první větu sinfonie.

Podrobné analýze pramene bude věnována samostatná studie, avšak již nyní lze říci, že pro provedení ve Vratislavi byla Orlandiniho Antigona výrazně upravena. ${ }^{21}$ Nejméně devět árií bylo nově zkomponováno, přičemž u šesti z nich známe díky tištěnému libretu a přípiskům v partituře jména autorů. Byli to kastráti Giovanni Dreyer a Filippo Finazzi, kteří byli zpěváky vratislavské společnosti a ve zmiňované opeře se uplatnili jako sólisté.

Nově lze k hudebním materiálům vratislavské opery dále přiřadit šest árií z opery Endimione dávané v karnevalu 1727. Skladatelem této opery byl Antonio Bioni, libreto obsahuje tři vložené árie v němčině (I/7 Amor schau! dich zu verwunden, II/2 Was soll ich thun? bekennen oder schweigen, III/3 Hör auf! hör auf zu klagen). Autorem prvních dvou

17 A-Wgm IV 27740 (Q 1214). Srovnej PERUTKOVÁ, 2011, op. cit., s. 51 (o vztahu Antonia Bioniho k Jaroměřicím), s. 359-360 (analýza kopistických rukou partitury). K provedení viz PERUTKOVÁ, 2015, op. cit., s. 483-484.

18 PL-KÓ BK 1669. BRISTIGER, Michał a Reinhard STROHM. „Libertà, marito e trono fur miei beni...": Die wiederentdeckte Andromaca von Antonio Bioni (Breslau 1730). In DUBOWY, Norbert, Corina HERR a Alina ŻÓRAWSKA-WITKOWSKA, ed. Italian Opera in Central Europe, 1614-1780. Volume 3: Opera Subjects and European Relationships. Berlin: BWV, 2007, s. 73-109. K novodobému provedení srovnej WEGRZYN-KLISOWSKA, op. cit., s. 197-213.

19 CZ-Pnm XLI D 1. Partitura je vázána v olejovém papíru převládající červené barvy s koženými růžky a hřbetem, rozměry desek $305 \times 235$. Rozměry listů po ořezu $295 \times 225$, ořízka zdobená červeným šplícháním. Pro opis byl použit jediný typ papíru s filigránem „trojlístek“, předsádka nese filigrán „poštovní trubka na korunovaném štítu“.

20 K otázce kopistů viz PERUTKOVÁ, 2011, op. cit., s. 359-360.

21 Jako srovnávací materiál sloužila partitura obsahující árie z Orlandiniho premiérové verze (Benátky 1718), uložená v US-SFsc *M2.5 v. 66. Za pomoc se získáním kopie partitury srdečně děkuji Martinu Lieblovi. Partitura Antigony v GB-Lbl Add. 16066 je ve skutečnosti druhou Orlandiniho verzí této opery, která byla provedena v Bologni 1727 pod názvem La fedeltà coronata. 
árií byl dle poznámek vytištěných na okraji libreta Daniel Gottlieb Treu, ${ }^{22}$ jejich hudba je dochována ve sbírce árií v Berlíně. ${ }^{23}$ Dle př́ípisu „Recitata dalla Sigra: Spinola Sotto il nome Aurilla" lze navíc určit jednu z interpretek opery (libreto neuvádí jména sólistů, Giacinta Spinola však byla dle jiných zdrojů v této době členkou vratislavské společnosti). ${ }^{24}$

Ze stejné opery pochází také čtyři árie Antonia Bioniho zachované ve svazku árií ve Schwerinu. ${ }^{25} \mathrm{Jsou}$ to tyto árie: Dice Tirsi ch'io son bella (I/3, soprán, Aurilla - tj. Giacinta Spinola), In questo seno io provo (I/3, tenor, Tirsi), Compatisco quegli amanti (II/4, alt, Endimione) a Usignolo che in vale ombroso (III/1, alt, Endimione).

Dochovaná libreta i hudební materiály poskytují cenné informace o vratislavském operním repertoáru, personálních otázkách, hlasových dispozicích sólistů a jejich skladatelském tvưrčím potenciálu. Posledním typem pramene, který je nutno na tomto místě alespoň stručně představit, je dobový tisk. Zásadní význam pro naše téma má periodikum Schlesischer Nouvellen-Courier, vycházející ve Vratislavi dvakrát týdně od roku 1708 do roku 1741 (a později pod názvem Schlesische Zeitung až do poloviny 20. století). ${ }^{26}$ Běžnou součástí domácích zpráv bylo také dění ve zdejším divadle - časopis informuje o nastudovaných titulech, nedávno přicestovalých pěveckých sólistech, upozorňuje na nově namalované dekorace, data jednotlivých představení, ceny vstupného apod. Jde o vynikající sondu do operního provozu menšího zaalpského města v 1. polovině 18. století, a proto nelze než litovat, že dobu zdejšího působení italské společnosti nepokrývá kompletně - zcela chybí ročníky 1725, 1727, 1729 a některá jednotlivá čísla. ${ }^{27}$ To je také zřejmě důvodem, proč je badateli zabývajícími se operou ve Vratislavi vesměs opomíjen; poslední, kdo s ním pracoval, byl Borcherdt.

Podrobná charakteristika pramene překračuje rámec tohoto přehledu, je však možno uvést alespoň několik příkladů ilustrujících široké spektrum informací, které je možno z časopisu ve vztahu ke zdejšímu opernímu provozu vyčíst.

Jako příklad personálních informací je možno uvést zmínky o altistovi Giovannim Dreyerovi, který dle Matthesona poprvé zpíval v Contiho opeře Il finto Policare dávané ve Vratislavi v dubnu $1726 .{ }^{28} \mathrm{~V}$ dochovaných libretech se Dreyer objevuje až do roku $1730,{ }^{29}$ později se uplatnil i jako impresário společnosti a př́íležitostný skladatel. Ozná-

22 „Von Hrn. Daniel Fedele“. Libreto PL-WRu Yv 983/2.

23 D-B Mus.ms.autogr. Agricola, J. F. 1, č. 10 a 11. Datace Endimiona do roku 1747 uváděná v záznamu je chybná.

24 MATTHESON, op. cit.

25 D-SWl Mus.4721, č. 89-92.

26 SCHIERSE, Bruno Bernhard. Das Breslauer Zeitungswesen vor 1742. Breslau: J. U. Kern, 1902.

27 Časopis byl studován z mikrofilmů získaných zápůjčkou z Mikrofilmarchiv und Mediathek, Staats- und Universitätbibliothek Bremen. Chybějící ročníky, které byly ztraceny již v Borcherdtově době, se nepodařilo najít. Oproti exemplářům uváděným Schiersem byly nově zjištěny pouze nekompletní ročníky 1731-1735 a 1738-1740 ve Vědecké knihovně v Olomouci (sign. 27.004, 27.006).

28 „Signore Dreyer, ein florentinischer Deutscher und Altcastrate, kam an des abgegangenen Vida Stelle“. MATTHESON, op. cit., s. 375. Paolo Vida byl falzetista, který krátce předtím odešel společně s Marií Giusti do Prahy.

29 Jeho jméno je uvedeno v těchto libretech (v chronologickém pořadí): 1727 - Ariodante (Ariodante), Atalo (Atalo), 1728 - Griselda (Gualtiero), Antigona vendicata (Osmene), 1729 - La fede tradita e vendicata (Ricimero), 
mení o Dreyerově příjezdu se v Schlesischer Nouvellen-Courier objevuje dne 2 . května; ${ }^{30}$ již 6. května poprvé vystoupil v divadle, ačkoli byl kvůli dlouhé cestě mírně hlasově indisponován. ${ }^{31}$ Vzhledem k tomu, že opera Il finto Policare měla premiéru již 25. dubna, ${ }^{32}$ není jasné, zda zůstala Dreyerova role do té doby neobsazena, či ji zpíval někdo jiný (libreto neuvádí jména sólistů).

V obsáhlejších anoncích, které zpravidla provázely uvedení nového titulu, nacházíme často zajímavé postřehy, ilustrující autentické náhledy na soudobou operní tvorbu. U opery Alba Cornelia Francesca Bartolomea Contiho je vyzdvihováno ústrojné začlenění komických scén, ${ }^{33}$ pozoruhodná je charakteristika Bioniho Artabana s áriemi „na způsob menuetů “. ${ }^{34} \mathrm{~V}$ pozvánce na operu barona d'Astorgy Dafni jsou vyzdvihovány italské buffo scény a árie v němčině, kterým bude moci každý rozumět. ${ }^{35}$

Z hlediska dobové provozovací praxe jsou velmi zajímavé poměrně četné zprávy týkající se árií nově vložených do té které opery v průběhu repríz. Z formulací jednoznačně vyplývá, že cizí hudba nebyla vnímána jako kontaminace stávajícího operního díla, nýbrž jako jeho obohacení či vylepšení a jako prostředek k přitáhnutí ochabujícího zájmu publika. ${ }^{36}$ Vysloveně pozitivně je hodnocena například opera La costanza di Griselda, která

Engelberta (Lodovico), Teseo in Creta (Teseo), 1730 - Andromaca (Pirro), Ercole su'l Termodonte (Ercole). Libreta z roku 1726 neuvádějí jména sólistů.

30 „NB. Allen Liebhaber-und Liebhaberin der Musiqve wird günstig zu wissen gethan, daß man, ohnerachtet einer so wenigen Besuchung, sich doch dahin befleisse, allhier etwas zu produciren, so in gantz Teutschland gewiß nicht zu finden ist, unter denen neu aus Italien verschriebenen, und zu dieser noch zu der Compagnie trettenden Virtuosen und Virtuosin ist würcklich der Gioanni Treiro ein Castrat, und Contre-Alt angekommen: gleich wie nun solcher auf den berühmtesten Wällschen Theatris grosse Approbation gefunden, und auf denen principalesten gefunden, also ist auch kein Zweifel, daß Er allhier dem gantzen Werck ein grosses Lustre geben werde; Bey der ersten zu haltenden Opera wird Er sich hören lassen; mithin verstehet man sich einer geneigten und gnädigen Besuchung." Schlesischer Nouvellen-Courier, 1726, č. 70, 2. 5. 1726.

31 „NB: Allen Liebhabern und Liebhaberinnen der Musique wird gehorsamst zu wissen gethan, daß der Castrat, der neue Virtuoso sich heut, als den 6ten hujus. wird hören lassen, wobey man hoffet, ein jedweder werde von seiner Kunst (obwohln er wegen der großgemachten Reise etwas heiser,) ein güttiges Contento schöpffen können, zumahlen ein Contre-Alto allhier noch nicht gehöret worden." Schlesischer Nouvellen-Courier, 1726, č. 71, 6. 5. 1726.

32 Schlesischer Nouvellen-Courier, 1726, č. 65, 25. 4. 1726.

33 „Diese Opera ist voller schönen u. tugendhafften Sentiments, die Music eines von denen vollkommensten Wercken, so noch nicht gehört worden; Ein Kenner der Music wird wissen, daß nicht leicht ein Compositore, so die Stärcke und den Genie in dem Patetischen hat, in dem Lustigen anmuthig spiele, darum werden auch meistentheils die Intramezzi von andern Federn gesuchet, als die Opera ist; Allhier aber wird gefunden, daß das Seriose mit dem Lächerlichen vermenget, ohne daß es denen beweglichen Begebenheiten der Historie und der Vorstellung der schönen Caracteren dieser Opera den geringsten Tort thun, so gewiß was besonderes ist, indeme der Autor dieser Musiqve in beyden gewiesen, daß Er ein grosser Meister sey [...]", Schlesischer Nouvellen-Courier, 1726, č. 29, 21. 2. 1726.

34 „Die gantze Vorstellung ist kurtz, und voller lustigen Arien, die in den Gout der Menueten lauffen [...]“, Schlesischer Nouvellen-Courier, 1728, č. 7, 12. 1. 1728.

35 „Die Composition der Musiqve ist von dem berühmten Cavallier Baron d'Astorga, ein Autor, von deme allhier in denen vorgewesenen Repraesentationen noch nichts gehöret worden: man flattiret sich gäntzlich, daß dieses Stück Approbation finden dürfte, zumahlen solches auch mit was lächerlichen und auf Wällisch, mit der parte buffa untermischet ist, deme noch beytritt, daß auch etliche Arien werden teutsch gesungen werden, damit Jedermann etwas davon verstehen könne." Schlesischer Nouvellen-Courier, 1726, č. 147, 16. 9. 1726.

36 „Es wird allen Liebhabern und Liebhaberin der Music gehorsamst zu wissen gethan, welcher gestalten 
byla jako pasticcio koncipována od samého začátku: jako kuriozita je vyzdvihováno zejména to, že jména „italských mistrů“ jsou v libretu vytištěna u každé árie zvlášt. ${ }^{37}$ Ve světle těchto zpráv je patrné, že moderní estetický názor na pasticcio jako podřadný operní žánr 18. století se zcela rozchází s dobovým pohledem, kdy bylo pasticcio chápáno jako rovnocenný protějšek nově zkomponovaného díla. V podmínkách zaalpského operního provozu navíc bylo zapojení hudby „prověřené“ z jiných míst považováno za známku kvality a záruku úspěchu.

Představené typy pramenů - libreta, partitury a dobový tisk - samozřejmě nepokrývají základnu pro výzkum opery ve Vratislavi v celé její šírii. Další zdroje informací bude nutno hledat v archivních materiálech, přičemž u mnohých, jako např. Borcherdtem zmiňovaných vratislavských městských akt a stavebních účtů, je nutno nejprve ověřit jejich současné uložení (či existenci). Velké naděje vzbuzují také dobové ego-dokumenty v čele s dosud jen částečně zpracovaným deníkem zemského hejtmana Otto Václava Nostice z let 1727-1729. ${ }^{38}$

Vratislavská operní stagiona 1725-1734 sice na první pohled působí jako epizoda bez hlubšího dopadu na místní hudební život, avšak pokud ji vnímáme v širším historickém i lokálním kontextu, není možné jí upřít její nezastupitelnou roli v pronikání italské opery za Alpy ve 20. letech 18. století. Vedle skutečnosti, že se de facto jedná o hudební kulturu českých zemí, je možno zájem o tuto tematiku podpořit také dosud zjištěnými konkrétními personálními i repertoárovými průniky s hudebním děním na území dnešní České republiky. Dá se také předpokládat, že víceméně kontinuální desetiletá tradice veřejně přístupných operních představení připravila půdu pro recepci tohoto žánru v okruhu slezských zámeckých kapel ve 2. polovině 18. století. V tomto ohledu má dosud česká hudební historiografie co dohánět; zdá se však, že na nedostatek materiálu si stěžovat nemůže.

man in der noch fortwehrenden Opera die Menge neue Arien von denen zwey Hn. Hn. Compositoren hat componiren, und einmengen lassen, die das Werck desto vollkommener machen werden: gleich wie nun die Diversität, und Abwechselungen in der Musiqve das Angenehmste zu senn scheinet, also versiehet man sich einer zahlreichen Besuchung, die man besonder zu contentiren verhoffet“ (o opeře Dafni). Schlesischer Nouvellen-Courier, 1726, č. 153, 26. 9. 1726. „Es wird allen gnädig. und geneigten Liebhabern und Liebhaberinnen der Music wissend gemacht, daß bey fortwehrendem Wollmarck die schöne Opera mit besonderer Veränderung der Arien alle Tag die Wochen durch praesentiret wird“ (o opeře Filindo). Schlesischer Nouvellen-Courier, 1728, č. 77, 13. 5. 1728. „Es wird allen gnädigen Liebhabern und Liebhaberinnen der Music wird gnädigst zu wissen gethan, daß an heuth wieder Veränderungen in denen Arien werden zu hören seyn, um das Publicum mit der Diversitaet zu bedienen“ (o opeře Antigona vendicata). Schlesischer Nouvellen-Courier, 1728, č. 165, 14. 10. 1728.

37 „[...] diese Opera hat aber eine Besonderheit in sich, welche alhier noch niemalen gesehen worden, massen solche nicht von einem Capell-Meister in die Music gesetzet worden, wie es ordinari geschiehet, und wie man alle vorherige Operen alhier produciret hat, sondern die Impressarii sind auf die Gedancken gefallen, die schönste Arien von denen grösten, und renomirtesten Männern von gantz Italien sich überschicken zu lassen, diese zusammen zu tragen, als dann die besten, und so am meisten à propos kommen, zu wehlen, und in dieser Opera zu setzen, also zwar, daß eine jede Aria schier von einem andern Meister gemachet worden; mithin die Differenz von Gusto, und die Stärcke so verschiedenen Compositionen nothwendiger Weise eine besondere Gefälligkeit erwecken solte, zumahlen in denen Operen-Bücheln die Authores von denen Arien jederzeit vermercket seyn, einfolglich ein solches Werck die Curiosität der allhiesigen Stadt würckl. verdienet [...]“, Schlesischer Nouvellen-Courier, 1728, č. 98, 17. 6. 1728.

38 Archiwum państwowe we Wrocławiu, Zbiór rękopisów archiwalnych, Hs. 573. Srovnej GEBAUER, Curt. Schlesischer Adel im Spätbarock. Nach Tagebüchern des Grafen Otto Wenzel von Nostitz, Landeshauptmann von Breslau. In Zeitschrift des Vereins für Geschichte Schlesiens, 1934, roč. 68, s. 133-167. Za upozornění na tento pramen děkuji Vladimíru Maňasovi. 


\section{Tabulka}

Tabulka udává v chronologickém pořadí všechny opery, které byly provedeny ve Vratislavi v letech 1725-1734. Informace o názvu, dataci provedení a skladateli jsou uvedeny jednak podle soupisu uvedeného v Matthesonově Grundlage einer Ehrenpforte (M), jednak na základě identifikovaných libret (L: libreto, i: italská verze, n: německá verze). Jednotlivé exempláře libret jsou odděleny středníkem, pro knihovny jsou použity zkratky dle katalogu RISM.

\begin{tabular}{|c|c|c|c|c|}
\hline & Název & Datace & Skladatel & Libreto / Partitura \\
\hline 1 & Orlando furioso (M) & 1725, Letnice (M) & Bioni (M) & \\
\hline 2 & $\begin{array}{l}\text { La costanza combattuta in } \\
\text { amore }(M, L i), \text { Die in der Liebe } \\
\text { angefochtene Beständigkeit } \\
(\text { Ln) }\end{array}$ & $\begin{array}{l}1725 \text {, léto }(M)(L \\
\text { pouze rok) }\end{array}$ & Porta (M) & \begin{tabular}{|l} 
PL-Wn BN.XVIII.2.6288 \\
(S.2.3453)
\end{tabular} \\
\hline 3 & Astarto (M) & 1725, podzim (M) & Treu (M) & \\
\hline 4 & \begin{tabular}{|l}
$\begin{array}{l}\text { Trionfo dell'amore }[\mathrm{e}] \\
\text { dell'amicizia }(\mathrm{M})\end{array}$ \\
\end{tabular} & 1725, zima (M) & Conti (M) & \\
\hline 5 & Cajo Martio Coriolano (M) & 1726, karneval (M) & Treu (M) & \\
\hline 6 & Alba Cornelia (L) (M: Comelia) & 1726, karneval (Ln) & Conti $(\mathrm{M}, \mathrm{L})$ & $\begin{array}{l}\text { I-Rsc Carv.407; US-Wc } \\
\text { ML48 [S2203] } \\
\end{array}$ \\
\hline 7 & $\begin{array}{l}\text { Il finto Policare (M), Die } \\
\text { verstellte Policare (Ln) }\end{array}$ & 1726, duben $(M, L)$ & Conti $(\mathrm{M}, \mathrm{L})$ & $\begin{array}{l}\text { I-Rsc Carv.6673; US-Wc } \\
\text { ML48 [S2201] }\end{array}$ \\
\hline 8 & Armida abandonata (M) & 1726, květen (M) & Bioni (M) & \\
\hline 9 & $\begin{array}{l}\text { Armida al campo (M, Li), Die } \\
\text { schöne Zauberin Armida (Ln) }\end{array}$ & 1726, červen $(M, L)$ & Bioni $(M, L)$ & I-Mb Racc.dram.5374 \\
\hline 10 & II Dafni (M) & 1726, záŕí (M) & d'Astorga (M) & \\
\hline 11 & $\begin{array}{l}\text { Ulisse e Telemaco (M), Vlisse } \\
\text { (Li), Vlisses (Ln) } \\
\end{array}$ & 1726, řijen $(M, L)$ & Treu $(M, L)$ & \begin{tabular}{|l|} 
D-Mth 001/8 R 00404; US- \\
Wc ML48 [S10444] \\
\end{tabular} \\
\hline 12 & Didone (M), Dido (Ln) & $\begin{array}{l}\text { 1726, listopad } \\
(\mathrm{M}, \mathrm{L})\end{array}$ & Albinoni $(M, L)$ & US-Wc ML48 [S90] \\
\hline 13 & Endimione (M), Endimion (Ln) & $\begin{array}{l}1727, \text { karneval } \\
(\mathrm{M}, \mathrm{L})\end{array}$ & Bioni $(M, L)$ & $\begin{array}{l}\text { PL-WRu Yv 983/2 } \\
\text { (inv.č.84835); US-Wc ML48 } \\
\text { [S1043] }\end{array}$ \\
\hline 14 & $\begin{array}{l}\text { Don Chisciotte (M), Don } \\
\text { Quixote in dem schwartzen } \\
\text { Gebürg (Ln) }\end{array}$ & $\begin{array}{l}\text { 1727, kaneval } \\
\text { (Ln) (M neuvádí } \\
\text { období) } \\
\end{array}$ & Treu $(M, L)$ & $\begin{array}{l}\text { PL-WRu 440165; PL-WRu } \\
\text { Yv 983/1 (inv.č.84835) }\end{array}$ \\
\hline 15 & $\begin{array}{l}\text { Lucio Vero (M), Lucius Verus } \\
\text { (Ln) }\end{array}$ & $\begin{array}{l}\text { 1727, květen }(M), \\
\text { duben }(\mathrm{L})\end{array}$ & Bioni $(M, L)$ & $\begin{array}{l}\text { PL-WRu Yv 983/5 } \\
\text { (inv.č.84835) }\end{array}$ \\
\hline 16 & Ariodante (M, Ln) & $\begin{array}{l}1727 \text { (M neuvádí } \\
\text { období) }\end{array}$ & \begin{tabular}{|l|} 
pasticcio, árie: \\
Bioni, Dreyer, \\
Orlandi [= \\
Orlandini], \\
Vivaldi (M)
\end{tabular} & $\begin{array}{l}\text { PL-WRu Yv 983/6 } \\
\text { (inv.č.84835) }\end{array}$ \\
\hline 17 & $\begin{array}{l}\text { Attalo ed Arsinoe (M), Die } \\
\text { unter dem Vertrug verdeckte } \\
\text { Wahrheit oder Attalus und } \\
\text { Arsinoe (Ln) } \\
\end{array}$ & $\begin{array}{l}\text { 1727, listopad } \\
(\mathrm{M}, \mathrm{L})\end{array}$ & Bioni $(M, L)$ & $\begin{array}{l}\text { PL-WRu Yv 983/3,4 } \\
\text { (inv.č.84835) }\end{array}$ \\
\hline 18 & Artabano (M) & 1728, karneval (M) & Bioni (M) & \\
\hline 19 & Filindo (M) & 1728, jaro $(\mathrm{M})$ & Bioni (M) & \\
\hline
\end{tabular}




\begin{tabular}{|c|c|c|c|c|}
\hline & Název & Datace & Skladatel & Libreto / Partitura \\
\hline 20 & $\begin{array}{l}\text { Griselda (M), La costanza di } \\
\text { Griselda (Li), Die beständige } \\
\text { Griselda (Ln) }\end{array}$ & 1728, léto $(M)$ & $\begin{array}{l}\text { Pasticcio, } \\
\text { árie: Bioni, } \\
\text { Boniventi, } \\
\text { Caldara, } \\
\text { Capelli, } \\
\text { Gasparini, } \\
\text { Giacomelli, } \\
\text { Händel, } \\
\text { Orlandini } \\
\text { Porpora, Porta, } \\
\text { Sarro, Verocai, } \\
\text { Vinci, Vivaldi, } \\
\text { recitativy a } \\
\text { intermezzo } \\
\text { Bioni (M, } \\
\text { L) [jména } \\
\text { skladatelů } \\
\text { vytištěna } \\
\text { v libretu u } \\
\text { každé árie] } \\
\end{array}$ & D-Btheob bez sign. \\
\hline 21 & $\begin{array}{l}\text { Antigona vendicata (Li) (M: } \\
\text { Antigone), Die gerochene } \\
\text { Antigona (Ln) }\end{array}$ & 1728, řijen $(M, L)$ & $\begin{array}{l}\text { Orlandini (M, } \\
\text { L) }\end{array}$ & CZ-Bm B373 \\
\hline 22 & Merope (M) & (M neuvádí) & $\begin{array}{l}\text { Pasticcio, } \\
\text { árie: Alberti, } \\
\text { Bioni, Caldara, } \\
\text { Dreyer, } \\
\text { Finazzi, Lotti, } \\
\text { Meneghetti, } \\
\text { Porta, Vinci, } \\
\text { Vivaldi, } \\
\text { recitativy Bioni }\end{array}$ & \\
\hline 23 & $\begin{array}{l}\text { La fede tradita e vendicata } \\
\text { (M), Die hintergangene und } \\
\text { gerochene Treu (Ln) }\end{array}$ & $\begin{array}{l}\text { 1729, karneval } \\
(M, L)\end{array}$ & Bioni $(M, L)$ & \begin{tabular}{|l} 
PL-WRu Yv 984/1 \\
(inv.č.84836)
\end{tabular} \\
\hline 24 & Constantino il grande (M) & 1729, květen $(\mathrm{M})$ & $\begin{array}{l}\text { "hudba od } \\
\text { nejlepších } \\
\text { italských } \\
\text { mistrü" (M) } \\
\end{array}$ & \\
\hline 25 & \begin{tabular}{|l|} 
Engelberta (M), L'innocenza \\
riconosciuta in Engelberta (Li), \\
Die erkandte Unschuld in der \\
Engelberta (Ln) \\
\end{tabular} & 1729 , léto $(M, L)$ & Bioni & $\begin{array}{l}\text { PL-WRu Yv 984/2 } \\
\text { (inv.č.84836) }\end{array}$ \\
\hline 26 & $\begin{array}{l}\text { Teseo in Creta (M), Theseus in } \\
\text { Creta (Ln) }\end{array}$ & 1729, podzim $(M, L)$ & $\begin{array}{l}\text { "hudba od } \\
\text { různých } \\
\text { skladatelů" (M) }\end{array}$ & $\begin{array}{l}\text { PL-WRu Yv 984/3 } \\
\text { (inv.č.84836) }\end{array}$ \\
\hline 27 & $\begin{array}{l}\text { [Andromaca] (M: Andromaco), } \\
\text { Andromache (Ln) }\end{array}$ & $\begin{array}{l}\text { 1730, karneval } \\
(M, L)\end{array}$ & Bioni $(M, L)$ & $\begin{array}{l}\text { I-Vgc Rolandi Mus 2B } \\
\text { rac; PL-WRu Yv 984/4 } \\
\text { (inv.č.84836) }\end{array}$ \\
\hline 28 & $\begin{array}{l}\text { Ercole su'l Termodonte (M, } \\
\text { Li), Hercules auf dem Fluße } \\
\text { Termodon (Ln) }\end{array}$ & 1730 , jaro $(M, L)$ & Bioni $(M, L)$ & $\begin{array}{l}\text { I-Mb Racc.dram.5549; PL- } \\
\text { WRu Yv 984/5 (inv.č.84836) }\end{array}$ \\
\hline
\end{tabular}


Počátky opery ve Slezsku - současný stav pramenů

\begin{tabular}{|c|c|c|c|c|}
\hline & Název & Datace & Skladatel & Libreto / Partitura \\
\hline 29 & Giuditta (M) & 1730, léto $(M)$ & \begin{tabular}{|l} 
"árie od \\
italských \\
mistrů" (M)
\end{tabular} & \\
\hline 30 & $\begin{array}{l}\text { Lucio Papirio (M, Li), Lucius } \\
\text { Papirius (Ln) }\end{array}$ & $\begin{array}{l}\text { 1731/32, zima } \\
(M, L)\end{array}$ & Bioni $(M, L)$ & $\begin{array}{l}\text { I-Mb Racc.dram.5358/002; } \\
\text { PL-WRu Yv 985/2 } \\
\text { (inv.č.84837); US-Wc ML48 } \\
\text { [S1044] }\end{array}$ \\
\hline 31 & $\begin{array}{l}\text { Siroe, rè di Persia }(M, L i), \\
\text { Siroe, König in Persien (Ln) }\end{array}$ & 1732, karneval (L) & Bioni $(M, L)$ & $\begin{array}{l}\text { I-Mb Racc.dram.5603; PL- } \\
\text { WRu 443795; PL-WRu Yv } \\
\text { 985/3 (inv.č.84837) }\end{array}$ \\
\hline 32 & Silvia (M, Li) & 1732, karneval (L) & \begin{tabular}{|l|} 
Bioni $(M)(L$ \\
neuvádí)
\end{tabular} & I-Mb Racc.dram.4547 \\
\hline 33 & $\begin{array}{l}\text { La verità conosciuta (L) (M: } \\
\text { sconosciuta), Die erkannte } \\
\text { Wahrheit (Ln) }\end{array}$ & 1732 , jaro $(M, L)$ & Bioni $(M, L)$ & $\begin{array}{l}\text { PL-WRu 445384; PL-WRu } \\
\text { Yv 985/4 (inv.č.84837) }\end{array}$ \\
\hline 34 & $\begin{array}{l}\text { II Demetrio }(M, L i) \text {, Demetrius } \\
(\operatorname{Ln})\end{array}$ & $\begin{array}{l}\text { 1732, léto }(M), \\
\text { červen }(L)\end{array}$ & \begin{tabular}{|l} 
"árie nejlepších \\
mistrü“ (M), \\
Bioni (L) \\
\end{tabular} & $\begin{array}{l}\text { I-Mb Racc.dram.5385; PL- } \\
\text { WRu Yv 986/1 (inv.č.84838) }\end{array}$ \\
\hline 35 & Issipile (M, Ln) & $\begin{array}{l}\text { 1732, podzim, } \\
\text { k biskupské volbě } \\
(M, L)\end{array}$ & Bioni (L) & I-Mb Racc.dram.5675/002 \\
\hline 36 & Allessandro severo (M) & 1733, léto $(M)$ & Bioni (M) & \\
\hline 37 & $\begin{array}{l}\text { Artaserse (Li) (M: Artasserse), } \\
\text { Artaxerxes (Ln) }\end{array}$ & $\begin{array}{l}\text { 1733, léto }(M) \text {, } \\
\text { červen }(L)\end{array}$ & $\begin{array}{l}\text { "od různých } \\
\text { mistrü" (M) }\end{array}$ & $\begin{array}{l}\text { I-Rsc Carv.1300; PL-WRu Yv } \\
\text { 986/2 (inv.č.84838) }\end{array}$ \\
\hline 38 & $\begin{array}{l}\text { L'odio placato (M), Die } \\
\text { ausgesöhnte Verbitterung } \\
(\mathrm{Ln})\end{array}$ & $\begin{array}{l}\text { 1733, léto }(M), \\
\text { záŕí }(L)\end{array}$ & Bioni $(M, L)$ & $\begin{array}{l}\text { PL-WRu Yv 986/3 } \\
\text { (inv.č.84838) }\end{array}$ \\
\hline 39 & Aglatida (M) & 1733, zima (M) & $\begin{array}{l}\text { "neznámý, } \\
\text { ale dobrý } \\
\text { skladatel" (M) }\end{array}$ & \\
\hline 40 & Alessandro nell'Indie (M) & 1734, karneval (M) & Bioni (M) & \\
\hline 41 & Orlando furioso (M) & (M neuvádí) & Bioni (M) & \\
\hline
\end{tabular}




\section{Zkratky knihoven}

$\begin{array}{ll}\text { A-Wgm } & \text { Wien, Archiv der Gesellschaft der Musikfreunde } \\ \text { CZ-Bm } & \text { Brno, Moravské zemské muzeum, Oddělení dějin hudby } \\ \text { CZ-Pnm } & \text { Praha, Národní muzeum - České muzeum hudby } \\ \text { CZ-OLu } & \text { Olomouc, Vědecká knihovna } \\ \text { D-B } & \text { Staatsbibliothek zu Berlin - Preußischer Kulturbesitz, Musikabteilung } \\ \text { D-Btheob } & \text { Berlin, soukromá sbírka Rainera Theobalda (není evidována v RISM) } \\ \text { D-Mth } & \text { München, Theatermuseum, Bibliothek } \\ \text { D-SWl } & \text { Schwerin, Landesbibliothek Mecklenburg-Vorpommern Günther Uec- } \\ & \text { ker, Musikaliensammlung } \\ \text { GB-Lbl } & \text { London, The British Library } \\ \text { I-Bc } & \text { Bologna, Museo internazionale e biblioteca della musica } \\ \text { I-Mb } & \text { Milano, Biblioteca Nazionale Braidense } \\ \text { I-Rsc } & \text { Roma, Biblioteca del Conservatorio di Musica Santa Cecilia } \\ \text { I-Vgc } & \text { Venezia, Biblioteca della Fondazione Giorgio Cini } \\ \text { PL-KÓ } & \text { Kórnik, Biblioteka Kórnicka Polskiej Akademii Nauk } \\ \text { PL-Wn } & \text { Warszawa, Biblioteka Narodowa } \\ \text { PL-WRu } & \text { Wrocław, Biblioteka Uniwersytecka } \\ \text { US-SFsc } & \text { San Francisco State University, Col. Frank V. de Bellis Collection } \\ \text { US-Wc } & \text { Washington, D.C., The Library of Congress }\end{array}$

\section{Bibliography}

\section{Sources}

I-Mb, Racc.dramm.2247. Giovanni Porta: La costanza combattuta in amore (Verona 1723), libreto.

I-Mb, Racc.dramm.2267. Giuseppe Maria Orlandini: Antigona (Benátky 1718), libreto.

I-Mb, Racc.dramm.1839. Giuseppe Maria Orlandini: Antigona (Benátky 1721), libreto.

I-Mb, Racc.dramm.0814. Giuseppe Maria Orlandini: Antigona (Benátky 1724), libreto.

I-Bc, Lo.3570. Giuseppe Maria Orlandini: Antigona (Pesaro 1723), libreto.

I-Bc, Lo.3572. Giuseppe Maria Orlandini: Antigona (Torino 1727), libreto.

I-Bc, Lo.3593. Giuseppe Maria Orlandini: La fedeltà coronata (Bologna 1727), libreto.

CZ-Pnm, XLI D 1. Anonym [Giuseppe Maria Orlandini - Giovanni Dreyer - Filippo Finazzi]: Antigona (Wrocław 1728), partitura.

US-SFsc, *M2.5 v. 66. Giuseppe Maria Orlandini: Antigona (Benátky 1718), partitura.

GB-Lbl, Add. 16066. Giuseppe Maria Orlandini: Antigona [La fedeltà coronata] (Bologna 1727), partitura.

A-Wgm, IV 27740 (Q 1214). Antonio Bioni: Issipile (Wrocław 1732), partitura.

PL-KÓ, BK 1669. Antonio Bioni: Andromaca (Wrocław 1730), partitura.

D-B, Mus.ms.autogr. Agricola, J. F. 1, č. 10 a 11. Daniel Gottlieb Treu: Amor schau! dich zu verwunden, Was soll ich thun? bekennen oder schweigen (árie z opery Endimione, Wrocław 1727).

D-SWl, Mus.4721. Antonio Bioni: Dice Tirsi ch'io son bella, In questo seno io provo, Compatisco quegli 
amanti, Usignolo che in vale ombroso (árie z opery Endimione, Wrocław 1727).

PL-WRu, 446736/XI - XVI. Schlesischer Nouvellen-Courier (1726, 1728, 1730-1733, nekompletní), nedochováno, Mikrofilmarchiv und Mediathek, Staats- und Universitätbibliothek Bremen, mikrofilm.

CZ-OLu, 27.004, 27.006. Schlesischer Nouvellen-Courier (1731-1735, 1738-1740, nekompletní).

Archiwum państwowe, Wrocław, Zbiór rękopisów archiwalnych, Hs. 573. Deníky Otto Václava Nostice.

\section{Literature}

BORCHERDT, Hans Heinrich. Geschichte der italienischen Oper in Breslau. Zeitschrift des Vereins für Geschichte Schlesiens. 1910, roč. 44, s. 18-51.

BRISTIGER, Michał a Reinhard STROHM. „Libertà, marito e trono fur miei beni...“: Die wiederentdeckte Andromaca von Antonio Bioni (Breslau 1730). In DUBOWY, Norbert, Corina HERR a Alina ŻÓRAWSKA-WITKOWSKA, ed. Italian Opera in Central Europe, 1614-1780. Volume 3: Opera Subjects and European Relationships. Berlin: BWV, 2007, s. 73-109.

FREEMAN, Daniel E. The Opera Theater of Count Franz Anton von Sporck in Prague. Studies in Czech Music 2, Stuyvesant - New York: Pendragon Press, 1992.

GEBAUER, Curt. Schlesischer Adel im Spätbarock. Nach Tagebüchern des Grafen Otto Wenzel von Nostitz, Landeshauptmann von Breslau. Zeitschrift des Vereins für Geschichte Schlesiens, 1934, roč. 68 , s. 133-167.

HAVLÍČKOVÁ, Margita. Berufstheater in Brünn 1668-1733, Brno: MU, 2012.

HAVLÍČKOVÁ, Margita. Profesionálni divadlo v královském městě Brně 1668-1733, Brno: JAMU, 2009.

JONÁŠOVÁ, Milada. I Denzio: tre generazioni di musicisti a Venezia e a Praga. Hudební věda. 2008, roč. 45 , č. 1-2, s. 57-114.

PEGAH, Rashid-Sasha. Antonio Bioni und seine „Cantate Musicali“ für Markgräfin Friderique Louise von Brandenburg-Ansbach. Jahrbuch für fränkische Landesforschung, 2012, roč. 72, s. 185-197.

PERUTKOVÁ, Jana - SPÁČILOVÁ, Jana. Italská opera na Moravě - fenomén stále aktuální. Opus musicum, 2005, roč. 37 , č. 5, s. 50-53.

PERUTKOVÁ, Jana. Der glorreiche Nahmen Adami. Johann Adam Graf von Questenberg (1678-1752) als Förderer der italienischen Oper in Mähren. Wien: Hollitzer, 2015.

PERUTKOVÁ, Jana. František Antonín Míca ve službách hraběte Questenberga a italská opera v Jaroméricich. Praha: KLP, 2011.

PERUTKOVÁ, Jana. Výsledky projektu „Italská opera na Moravě v 1. polovině 18. století“ se zvláštním zřetelem k nově identifikované sbírce partitur hraběte Johanna Adama Questenberga (1678-1752). Miscellanea z výročnich konferenci ČSHV. Praha: EÚ AV ČR, 2008, s. 126-134.

SARTORI, Claudio. I libretti italiani a stampa dalle origini al 1800. Catalogo analitico con 16 indici. Cuneo: Bertola e Locatelli, 1990-1994.

SEHNAL, Jiří. Počátky opery na Moravě. Současný stav vědomostí. In PETRŮ, Eduard, ed. $O$ divadle na Moravě. AUPO, Facultas philosophica, Supplementum 21. Praha: SPN, 1974, s. 55-77.

SCHIERSE, Bruno Bernhard. Das Breslauer Zeitungswesen vor 1742. Breslau: J. U. Kern, 1902.

SPÁČILOVÁ, Jana. Catalogue of the Italian Opera Libretti in Central Europe in the 1st Half of the 18th Century, I: Moravia. Clavis monumentorum musicorum regni Bohemiae, series S, VIII. Praha: KLP, v tisku. 
Verzeichnis aller welschen Opern, welche von 1725 bis 1734 auf dem breslauischen Schauplatz vorgestellet worden sind. In MATTHESON, Johann. Grundlage einer Ehrenpforte, Hamburg, 1740, s. 374-378.

VEVERKOVÁ, Zuzana. Antonio Bioni - životní osudy a tvorba neznámého skladatele. Opus musicum, 2012, roč. 44, č. 3, s. 38-47.

VOLEK, Tomislav. Italská opera a další druhy zpívaného divadla. In ČERNÝ, František, ed. Divadlo v Kotcích. Nejstarši pražské městské divadlo 1739-1783, Praha: Panorama, 1992, s. 43-56.

WEGRZYN-KLISOWSKA, Walentyna. Barokowy teatr operowy we Wroctawiu 1725-1734. Wrocław: PSPŚ, 2006. 